Volume 16, No. 2, Juli 2019

Page: 775- 782

\title{
PENGARUH FORMULASI EKSTRAK BIJI KETUMBAR (Coriandrum sativum) SEBAGAI REPELLENT NYAMUK AEDES SP.
}

\author{
Nazilia Rizqi Fitriani, Sri Muryani, S. Eko Windarso \\ Poltekkes Kemenkes Yogyakarta Jurusan Kesehatan Lingkungan \\ Jl.Tatabumi 3, Banyuraden, Gamping, Sleman, DIY 55293 \\ E-mail: naziliarizqifitriani14@gmail.com
}

\begin{abstract}
Effect of Coriander Seed Extract Formulation (Coriandrum sativum) as Repellent to Mosquito Aedes sp. Dengue Hemorrhagic Fever (DHF) is an infectious disease caused by the dengue virus and transmitted through the bite of the Aedes aegypti mosquito. Vector control of the Aedes mosquito can use natural and safer ways, one of which is by using coriander seeds (Coriandrum sativum). The purpose of this study was to determine the effect of coriander seed extract formulation in the Gel Air Freshener as a repellent against the resistance of Aedes mosquitoes. This type of research is an experiment with a post-test only with control Group Design. The repellent used is made from a mixture of coriander seed extract (Coriandrum sativum) and Gel Air Freshener with 3 formulations. Research sample in the form of Aedes mosquito. the results of egg hatching were obtained from the installation of ovitrap in one of the houses in Jalan Langenastran Kidul as many as 600 for 6 repetitions. The data obtained were analyzed by One Way Anova test at 95\% confidence level).Based on the results of the repellent research on Aedes mosquitoes in the amount of $50.7 \%$ formulation $A, 58.7 \%$ formulation $B$ and $62.7 \%$ formulation $C$. The statistical test results showed each value of $p=0,000(p<0.05)$, meaning there significant differences in the use of Gel Air Freshener coriander seeds as a repellent against the Aedes mosquito. The conclusion of this study is that there are significant differences in the effect of variations in coriander seed extract formulations and Gel Air Freshener as a repellent of the Aedes mosquito with the most effective formulation $C$.
\end{abstract}

Keywords: Dengue Hemorrhagic Fever (DHF); Aedes sp.; Water Freshener Gel; Coriandrum Sativum

\begin{abstract}
Abstrak: Pengaruh Formulasi Ekstrak Biji Ketumbar (Coriandrum Sativum) sebagai Repellent Nyamuk Aedes Sp. Deman Berdarah Dengue (DBD) adalah penyakit menular yang disebabkan oleh virus dengue dan ditularkan melalui gigitan nyamuk Aedes aegypti. Pengendalian vektor nyamuk Aedes dapat menggunakan cara alamiah dan lebih aman, salah satunya dengan memanfaatkan biji ketumbar (Coriandrum sativum). Tujuan penelitian ini mengetahui pengaruh formulasi ekstrak biji ketumbar dalam Gel Air Freshener sebagai repellent terhadap daya tolak nyamuk Aedes. Jenis penelitian ini adalah eksperimen dengan rancangan post test only with control Group Design. Repellent yang digunakan terbuat dari campuran ekstrak biji ketumbar (Coriandrum sativum) dan Gel Air Freshener dengan 3 formulasi. Sampel penelitian berupa nyamuk Aedes. hasil penetasan telur yang diperoleh dari pemasangan ovitrap di salah satu rumah Jalan Langenastran Kidul sebanyak 600 ekor untuk 6 kali pengulangan. Data yang diperoleh dianalisis dengan uji One Way Anova pada derajat kepercayaan 95\%). Berdasarkan hasil penelitian repellent terhadap nyamuk Aedes sebesar 50,7\% formulasi A, 58,7\% formulasi B dan 62,7\% formulasi $C$. Hasil uji statistik menunjukkan masing-masing nilai $p=0,000(p<0,05)$, artinya ada perbedaan yang bermakna penggunaan Gel Air Freshener biji ketumbar sebagai repellent terhadap nyamuk Aedes. Kesimpulan penelitian ini adalah ada perbedaan bermakna pengaruh variasi formulasi ekstrak biji ketumbar dan Gel Air Freshener sebagai repellent nyamuk Aedes dengan yang paling efektif pada formulasi $C$.
\end{abstract}

Kata Kunci: Deman Berdarah Dengue (DBD); Aedes sp.; Gel Air Freshener; biji ketumbar 


\section{PENDAHULUAN}

Penyakit menular sampai saat ini masih menjadi penyebab tingginya angka kesakitan dan kematian penduduk Indonesia. Lingkungan hidup di daerah tropis yang lembab dan bersuhu hangat seperti Indonesia yang merupakan tempat hidup ideal bagi arthropoda/serangga untuk berkembangbiak. Banyak serangga yang dapat menimbulkan gangguan kesehatan, selain itu juga dapat bertindak sebagai vektor penyakit[1]. Vektor adalah arthropoda/serangga yang dapat menularkan, memindahkan dan/atau menjadi sumber penular penyakit terhadap manusia[2].

Salah satu serangga yang bertindak sebagai vektor penyakit adalah nyamuk. Nyamuk merupakan salah satu vektor berbagai macam penyakit menular yang disebabkan oleh virus dan mikroorganisme lainnya yang dapat mengakibatkan penyakit pada manusia seperti malaria, filariasis, chikungunya dan demam berdarah. Deman Berdarah Dengue (DBD) adalah penyakit deman akut yang disebabkan oleh empat serotype virus dengue dan ditandai dengan empat gejala klinis utama yaitu demam yang tinggi, manifestasi pendarahan, hematomegali dan tanda-tanda kegagalan sirkulasi sampai timbulnya renjatan (sindrom renjatan dengue) sebagai akibat dari kebocoran plasma yang dapat menyebabkan kematian [3].

Berdasrkan Profil Kesehatan Kabupaten Sleman (2013) Penyakit DBD merupakan penyakit endemis di Kabupaten Sleman dan endemis nasional. Jumlah kasus DBD pada tahun 2012 tercatat 236 kasus dengan kematian 0. Jumlah kasus ini naik dibandingkan tahun lalu dimana tahun 2012 jumlah kasus 166 dan kematian 0. Dilihat dari siklus kejadian kasus DBD di Kabupaten Sleman dari tahun 2002 sampai dengan tahun 2012 kasus tertinggi terjadi pada tahun 2007 sebesar 755. Adapun 6 Kecamatan yang mempunyai kasus tertinggi berturut-turut adalah Gamping, Godean, Kalasan, Mlati, Ngaglik dan Sleman[4]. Nyamuk Aedes sp lebih suka menggigit di daerah yang terlindung seperti disekitar rumah.
Nyamuk Aedes sp aktif menghisap darah pada siang hari (day biting mosquito) dengan 2 puncak aktivitas, yaitu pada pukul 08.00-12.00 dan 15.00-17.00[5].

Upaya pemberatasan penyakit DBD yang disebabkan oleh nyamuk Aedes aegypti dilakukan dengan peran serta masyarakat dan pemerintah yang berusaha bersama-sama peduli dan memahami bahaya yang ditimbulkan penyakit ini[6]. Saat ini banyak masyarakat yang lebih memilih menggunakan insektisida berbahan kimia yang dianggapnya praktis, efektif dan mudah diaplikasikan, namun sebenarnya senyawa tersebut berbahaya bagi kesehatan dan lingkungan karena sifatnya yang sulit terurai[7].

Alternatif pengendalian vektor penyakit DBD dapat menggunakan cara alamiah dan lebih aman yaitu memanfaatkan tanaman insektisida nabati yang mengandung senyawa Linalool. Linalool dapat menyebabkan racun kontak yang meningkatkan aktivitas sensorik pada serangga sehingga menyebabkan kejang dan kelumpuhan pada beberapa serangga. Bahan aktif linalool dari minyak atsiri banyak diminati oleh masyarakat karena baunya yang harum, aman bagi kesehatan dan mempunyai potensi pengendali nyamuk. Salah satu tanaman yang belum banyak dikaji dan menghasilkan minyak atsiri adalah ketumbar (Coriandrum sativum) ${ }^{[8]}$. Manfaat tanaman ini dapat digunakan sebagai repelan atau dapat mengusir nyamuk. Kandungan linalool atau koriandrol pada ketumbar sebesar 60$70 \%$, termasuk senyawa terpenoid alkohol, berbentuk cair, tidak berwarna dan beraroma wangi[9].

Biji ketumbar (Coriandrum sativum) selain mengandung minyak atsiri seperti senyawa linalool juga mengandung senyawa seperti saponin, flavonoid dan tanin. Coriandrum sativum adalah buah kering yang mengandung minyak atsiri sebesar $0,5 \%$. Minyak atsiri ini $40 \%$ terdapat di dalam kulit dan $60 \%$ di dalam biji. Komponen minyak atsiri antara lain 60-70\% (+) linalool (koriandrol), 20\% berbagai senyawa hidrokarbon, seperti $\alpha$ - 
pinena, $\gamma$-terpinena, limonena, $p$-simena, geraniol, borneol, sitronelol, bersama sama keton aldehida dan ester [10].

Berdasarkan hasil uji pendahuluan menggunakan Gel Air Freshener ekstrak biji ketumbar (Coriandrum sativum) dengan formulasi $5 \mathrm{ml}$ dan $25 \mathrm{ml} \mathrm{Gel} \mathrm{Air}$ Freshener yang dilakukan pada 03 Februari 2017, didapatkan hasil pada pengamatan jam pertama presentase daya terhadap menolak nyamuk adalah $48 \%$ dengan waktu pengukuran selama 10 menit. Jam kedua didapatkan prosentase daya menolak nyamuk adalah $40 \%$. Jam ketiga didapatkan presentase daya menolak nyamuk 0\% karena jumlah nyamuk tidak ada yang berpindah. Hasil tersebut belum memenuhi kriteria yang dapat menolak nyamuk sampai $90 \%$ selama 6 jam. Untuk itu dalam penelitian ini akan menggunakan formulasi sebanyak $10 \mathrm{ml}, 15 \mathrm{ml}$ dan $20 \mathrm{ml}$ pada volume $30 \mathrm{ml}$, dan diharapkan dapat diketahui formulasi ekstrak biji ketumbar (Coriandrum sativum) yang dapat menolak nyamuk paling banyak.

\section{BAHAN DAN CARA PENELITIAN}

Jenis penelitian ini adalah eksperimen dengan desain penelitian yang digunakan adalah post test only with control group yang hasilnya akan dianalisis secara deskriptif dan analiik.

Populasi dalam penelitian ini adalah semua nyamuk Aedes sp. hasil penetasan telur nyamuk yang diperoleh di daerah Jalan Langenasran Kidul. Selanjutnya, sebanyak 600 ekor nyamuk Aedes sp. yang diambil secara acak dijadikan sampel dalam penelitian ini dan digunakan untuk pengujian pada tiga kelompok perlakuan dan satu kelompok kontrol dalam 6 kali pengulangan.

Variabel bebas dalam penelitian ini adalah variasi formulasi ekstrak biji ketumbar dengan volume $30 \mathrm{ml}$ yang komposisinya bervariasi sebagai berikut: 1) Formulasi A yang berupa perbandingan antara $10 \mathrm{ml}$ ekstrak biji ketumbar dan 20 ml Gel Air Freshener. 2) Formulasi B yang berupa perbandingan antara $15 \mathrm{ml}$ ekstrak biji ketumbar dan $15 \mathrm{ml}$ Gel Air Freshener. 3) Formulasi $C$ yang berupa perbandingan antara $20 \mathrm{ml}$ ekstrak biji ketumbar dan 10 $\mathrm{ml}$ Gel Air Freshener. Variabel terikat yang diamati dalam penelitian ini adalah banyaknya nyamuk Aedes sp. yang menghindar ketika dipaparkan dengan $\mathrm{Gel}$ Air Freshener dari ekstrak biji ketumbar (Coriandrum sativum) yang didiamkan selama 30 menit dengan waktu pemaparan 6 jam dan diukur pada setiap jamnya. Variabel pengganggu yang dikendalikan dalam penelitian adalah: 1) umur nyamuk, yaitu menggunakan nyamuk Aedes sp. yang berumur antara 34 hari; 2) jenis kelamin nyamuk, yaitu nyamuk Aedes sp. betina; 3) waktu pengamatan, yaitu waktu pengamatan pada pagi hari (08.00-14.00).

Alat yang digunakan dalam penelitian meliputi: ovitrap, nampan, mangkok, pipet mulut lebar, sangkar nyamuk, kompor, pengaduk, aspirator, wadah Gel Air Freshener, stopwatch, paper cup. Adapun bahan yang digunakan adalah ekstrak biji ketumbar (Coriandrum sativum), larutan gula $10 \%$, kertas saring, air, pelet, nyamuk Aedes sp., bahan Gel Air Freshener.

Tahap pelaksanaan penelitian tentang efektifitas Gel Air Freshener anti nyamuk terdiri dari: 1) Menyiapkan 4 buah kotak uji; 2) Menyiapkan ekstrak biji ketumbar dalam Gel Air Freshener; 3) Memasukkan nyamuk Aedes sp. masingmasing kotak uji 25 ekor; 4) Meletakkan ekstrak biji ketumbar dalam Gel Air Freshener; 5) Membuka lubang pada lorong yang ditutup dengan tutup botol; 5) Mengamati dan menghitung jumlah nyamuk Aedes sp. yang mengindar.

Pengujian efektifitas Gel Air Freshener tersebut sebagai repellent bagi nyamuk Aedes sp. dilakukan pada kisaran pukul 08.00 - 14.00 WIB, dilakukan perhitungan dan pencatatan jumlah nyamuk yang menghindar pada setiap jamnya. Penelitian dilakukan selama 6 hari. Dalam satu hari penelitian hanya dilakukan satu kali pengulangan untuk masingmasing perlakuan. Data yang diperoleh dianalisis secara deskriptif dan analitik. Analisis statistik yang digunakan adalah uji parametric one way anova pada derajat kepercayaan $95 \%(\alpha=0,05)$. 


\section{HASIL DAN PEMBAHASAN}

Jumlah nyamuk Aedes sp. Yang menghindar akibat Gel Air Freshener anti nyamuk selama 6 jam dapat dilihat pada Tabel 1.

Tabel 1.Jumlah Nyamuk yang Pindah dari Kotak A ke Kotak B dengan Pemaparan Formulasi A, B, C dan Kontrol Selama 10 Menit Pertama Setiap Jam.

\begin{tabular}{|c|c|c|c|c|c|}
\hline \multirow{2}{*}{$\begin{array}{c}\text { Waktu } \\
\text { pengukuran }\end{array}$} & \multirow{2}{*}{ Pengulangan } & \multicolumn{4}{|c|}{$\begin{array}{l}\text { Formulasi Gel Air Freshener Ekstrak Biji Ketumbar } \\
\text { (Coriandrum sativum) }\end{array}$} \\
\hline & & Formulasi A & Formulasi B & Formulasi C & Kontrol \\
\hline \multirow{6}{*}{ Jam Pertama } & 1 & 4 & 6 & 9 & 0 \\
\hline & 2 & 5 & 7 & 8 & 0 \\
\hline & 3 & 4 & 6 & 9 & 2 \\
\hline & 4 & 6 & 5 & 7 & 1 \\
\hline & 5 & 6 & 6 & 8 & 1 \\
\hline & 6 & 5 & 7 & 8 & 2 \\
\hline \multirow{6}{*}{ Jam Kedua } & 1 & 8 & 10 & 13 & 2 \\
\hline & 2 & 10 & 11 & 13 & 2 \\
\hline & 3 & 9 & 10 & 12 & 2 \\
\hline & 4 & 9 & 9 & 11 & 2 \\
\hline & 5 & 9 & 11 & 13 & 3 \\
\hline & 6 & 9 & 11 & 13 & 3 \\
\hline \multirow{6}{*}{ Jam Ketiga } & 1 & 13 & 13 & 15 & 2 \\
\hline & 2 & 12 & 13 & 15 & 2 \\
\hline & 3 & 12 & 12 & 13 & 3 \\
\hline & 4 & 13 & 11 & 13 & 3 \\
\hline & 5 & 14 & 13 & 13 & 4 \\
\hline & 6 & 14 & 13 & 14 & 4 \\
\hline \multirow{6}{*}{ Jam Keempat } & 1 & 13 & 15 & 16 & 3 \\
\hline & 2 & 13 & 16 & 17 & 3 \\
\hline & 3 & 12 & 14 & 15 & 4 \\
\hline & 4 & 14 & 14 & 15 & 4 \\
\hline & 5 & 14 & 17 & 17 & 4 \\
\hline & 6 & 15 & 17 & 16 & 4 \\
\hline \multirow{6}{*}{ Jam Kelima } & 1 & 14 & 18 & 19 & 3 \\
\hline & 2 & 15 & 18 & 19 & 3 \\
\hline & 3 & 15 & 17 & 18 & 4 \\
\hline & 4 & 16 & 16 & 17 & 5 \\
\hline & 5 & 16 & 18 & 20 & 5 \\
\hline & 6 & 15 & 19 & 18 & 5 \\
\hline \multirow{6}{*}{ Jam Keenam } & 1 & 14 & 19 & 22 & 3 \\
\hline & 2 & 17 & 20 & 21 & 4 \\
\hline & 3 & 16 & 18 & 21 & 5 \\
\hline & 4 & 18 & 18 & 20 & 5 \\
\hline & 5 & 17 & 20 & 22 & 5 \\
\hline & 6 & 17 & 21 & 22 & 5 \\
\hline
\end{tabular}

Berdasarkan Tabel 1 tersebut jumlah nyamuk yang pindah dari jam pertama sampai jam keenam pada formulasi A paling banyak pada jam ke 6 
pengulangan 4 yaitu 18 ekor dan paling sedikit pada jam pertama pengulangan 1 dan 3 yaitu 4 ekor, sedangkan pada formulasi B paling banyak pada jam ke 6 pengulangan 6 yaitu 21 ekor dan paling sedikit pada jam pertama pengulangan 4 yaitu 5 ekor, formulasi $\mathrm{C}$ paling banyak pada jam ke 6 pengulangan 3,4,5,6 yaitu 5 ekor dan paling sedikit pada jam pertama pengulangan 4 yaitu 7 ekor, serta pada kontrol paling banyak pada jam ke 6 pengulangan 4 yaitu 18 ekor dan paling sedikit pada jam pertama pengulangan 1 dan 2 yaitu 0 ekor.
Adapun untuk mengetahui daya proteksi masing-masing perlakuan repellent Gel Air Freshener esktrak biji ketumbar maka dilakukan perhitungan pada jam keenam dengan rumus daya proteksi kemudian di masukkan ke dalam tabel 2. Berdasarkan Tabel 2 tersebut diketahui bahwa rata-rata jumlah nyamuk Aedes sp. yang menghindar akibat pemaparan Gel Air Freshener tersebut pada kelompok kontrol adalah 3 ekor dan pada kelompok perlakuan sebanyak 12 ekor pada formulasi A, 14 ekor pada formulasi B dan 15 pada formulasi C.

Tabel 2. Daya Repellent Nyamuk yang Pindah dari Kotak A ke Kotak B dengan Pemaparan Formulasi A, B, C dan Kontrol Selama 10 Menit Pertama Setiap Jam.

\begin{tabular}{ccccc}
\hline \multirow{2}{*}{ Pengulangan } & \multicolumn{4}{c}{ Rata-Rata Nyamuk yang Pindah ke Kotak B (ekor) } \\
\cline { 2 - 5 } & Formulasi A & Formulasi B & Formulasi C & Kontrol \\
\hline 1 & 11 & 14 & 16 & 2 \\
2 & 12 & 14 & 16 & 2 \\
3 & 11 & 13 & 15 & 3 \\
4 & 13 & 12 & 14 & 3 \\
5 & 13 & 14 & 16 & 4 \\
6 & 13 & 15 & 15 & 4 \\
\hline
\end{tabular}

Selanjutnya, Grafik $\quad 1$ memperlihatkan kekuatan penolakan dari ketiga repellent yang ditunjukkan dengan banyaknya nyamuk Aedes sp. yang

menghindar pada setiap pengulangannya, baik di kelompok kontrol maupun di ketiga kelompok perlakuan.

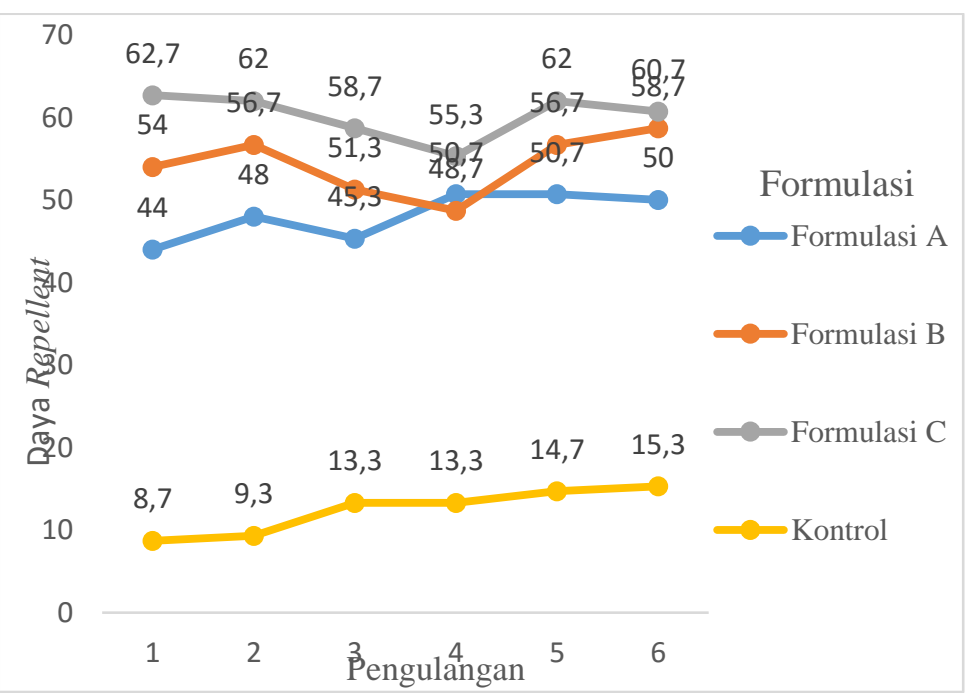

Grafik 1 Grafik Jumlah Nyamuk Aede sp. yang Menghindar Akibat Pemaparan Formulasi A, B dan C selama 6 jam (Setiap Jam)

Grafik di atas menunjukkan adanya perbedaan jumlah nyamuk Aedes sp., semakin besar formulasinya maka semakin besar pula daya repellentnya. 
Dari hasil tersebut daya repellent paling efektif terjadi pada formulasi C, hal ini menunjukkan kemampuan repellent Gel Air Freshener ekstrak biji ketumbar masih mampu menolak nyamuk sampai jam keenam.

Berdasarkan hasil penelitian dapat diketahui bahwa ekstrak biji ketumbar mempunyai kemampuan sebagai penolak nyamuk Aedes sp. Hasil penelitian menunjukan rata-rata kemampuan repellent tertinggi pada kelompok kontrol adalah 15,3\%, formulsi A sebesar 50,7\%, formulasi B sebesar $58,7 \%$ dan formulasi C sebesar $62,7 \%$. Hal tersebut menunjukkan bahwa rata-rata persentase nyamuk Aedes sp. yang menghindar paling banyak terjadi pada kelompok eksperimen formulasi $\mathrm{C}$ yaitu $62,7 \%$.

Hasil penelitian yang sudah dilaksanakan, presentase daya repellent yang dihasilkan dari masing-masing formulasi mengalami kenaikan dan penurunan ditiap pengulagan yang berbeda-beda. Hal ini disebabkan cuaca lingkungan yang berubah-ubah setiap pengulangannya. Cuaca lingkungan yang mepengaruhi naik turunnya presentase daya proteksi antara lain suhu ruangan dan kondisi kotak uji. Faktor suhu ruangan penelitian mampu mempengaruhi naik turunnya persentase daya proteksi di masing-masing formulasi, hal ini disebabkan suhu dan kelembaban dapat menunjukkan keadaan optimal bagi nyamuk untuk hidup, tumbuh, berkembang, beraktivitas, dan mencari makan. Penelitian ini dilakukan di pagi hingga siang hari menjadikan suhu ruangan penelitian semakin panas pada siang harinya, hal ini dapat memicu penguapan repellent semakin cepat.

Nyamuk Aedes sp. yang menghindar dalam penelitian ini dikarenakan bahan aktif yang terkandung pada biji ketumbar (Coriandrum sativum). Hampir semua tanaman mempunyai senyawa aktif yang dapat digunakan untuk pencegah serangga. Senyawa - senyawa ini dapat berupa feeding, toksin dan repellent, salah satu tanaman yang dapat digunakan untuk menolak nyamuk adalah biji ketumbar. Biji ketumbar memiliki kandungan kimia berupa senyawa flavonoid, dan saponin[10].

Flavonoid adalah salah satu jenis senyawa yang bersifat racun/aleopati. Flavonoid mempunyai sifat yang khas yaitu bau yang sangat tajam, sebagian besar merupakan pigmen warna kuning, dapat larut dalam air dan pelarut organik, mudah teruri pada temperature tinggi flavonoid ke dalam mulut serangga melalui sistem pernapasan berupa spirakel yang terdapat dipermukaan tubuh dan menimbulkan kelayuan syaraf, serta kerusakan pada spirakel akibatnya tidak bisa bernapas dan akhirnya mati. Flavonoid mempunyai efek toksik dan penolak serangga[11].

Saponin merupakan senyawa berasa pahit menusuk, menyebabkan bersin dan sering menyebabkan iritasi terhadap selaput lendir. Saponin adalah suatu glikosida alamiah yang terikat dengan steroid atau triterpena. Saponin mempunyai aktifitas farmakologi yang cukup luas diantaranya meliputi: immunomodulator, anti tumor, anti inflamasi, antivirus, anti jamur, dapat membunuh kerang-kerang, hipoglikemik, dan efek Hypokholesterol serta bersifat racun bagi serangga kecil. Saponin dapat bersifat menghancurkan butir darah merah lewat rekasi hemolysis. Saponin juga dapat merusak kulit nyamuk sehingga enzim pernafasan terhambat dan menganggu organ pernafasan ${ }^{[12]}$.

Repellent adalah bahan kimia yang berfungsi sebagai penolak, baik itu untuk serangga maupun hewan yang lain[13]. Repellent yaitu bahan kimia atau nonkimia yang berkhasiat mengganggu kemampuan insekta untuk mengenal bahan atraktan dari hewan atau manusia. Bahan terserbut memblokir fungsi sensori pada nyamuk. Jika digunakan dengan benar, repelen nyamuk bermanfaat untuk memberikan perlindungan pada individu pemakaianya dari gigitan nyamuk selama jangka waktu tertentu[14]. Menurut Komisi Pestisida Departemen Pertanian dalam Susilowati dan Kurniawati (2010) repellent dikatakan efektif jika memiliki daya proteksi $90 \%$ dan bertahan selama 6 jam. 
Walaupun hasil penelitian terhadap bahan alami biji ketumbar ini belum menunjukkan hasil yang belum memenuhi standar menurut Komisi Pestisida Departemen Pertanian RI, yaitu harus memiliki daya proteksi $90 \%$ selama enam jam, namum hal ini merupakan suatu harapan dan potensi biji ketumbar yang perlu digali, mengingat dampak negatif yang ditimbulkan dari penggunaan bahan kimia sintetis beracun (pestisida) terhadap kesehatan manusia yang cukup besar.

Penggunaan ekstrak biji ketumbar dalam bentuk Gel Air Freshener sebagai repellent nyamuk Aedes sp. memiliki tujuan untuk mengurangi penyebaran penyakit Demam Berdarah Dengue (DBD) dengan cara menghindari hisapan nyamuk Aedes sp. DBD dapat menyerang manusia bahkan anak kecil dan memiliki risiko kematian serta menimbulkan wabah atau kejadian luar biasa (KLB).

Bahan-bahan aktif yang terkandung dalam biji ketumbar (Coriandrum sativum) tersebut menguap akibat panas yang berada di ruangan. Menurut Surya (2011), nyamuk memiliki kemampuan untuk mencari mangsa dengan mencium bau karbondioksida, asam laktat, dan bau lainnya yang berasal dari kulit yang hangat dan lembab. Nyamuk sangat sensitif dengan bahan kimia tersebut, sehingga dapat mendetekdi darah yang merupakan makanannya dengan jarak 2,5 meter. Umumnya repellent akan memanipulasi bau dan rasa yang berasal dari kulit dengan menghambat reseptor asam laktat pada antena nyamuk sehingga mencegah nyamuk mendekati kulit[15].

Penelitian ini sejalan dengan penilitian Ikhsanudin (2012) yang berjudul formulasi Vanishing cream minyak atsiri rimpang jahe (Zingiber officinale Roxb) dan uji aktifitas repelan terhadap nyamuk Aedes aegypti betina. Hasil dari penelitian ini adalah didapatkan bahwa minyak atsiri rimpang 25\% memiliki kemampuan daya repellent Aedes aegypti selama 47,2 menit[16].

Penelitian serupa juga pernah dilakukan oleh Niken (2014) dengan judul Pengaruh Variasi Konsentrasi Ekstrak
Bunga Kamboja (Plumeria alba) dalam Lotion sebagai Repellent terhadap Daya Tolak Nyamuk Aedes sp. Hasil penelitian menunjukkan bahwa variasi konsentrasi ekstrak bunga kamboja yang digunakan berbeda secara signifikan $(p=0,039)$ terhadap daya tolak nyamuk Aedes sp. dimana konsentrasi $40 \%$ adalah yang paling efektif dengan persentase daya tolak pada jam pertama dan ke lima masing-masing sebesar sebesar 83,81\% dan 3,52\%[15].

Ninda (2014) pernah melakukan penelitian tentang "Penggunaan Mat Serbuk Daun Kemangi (Ocimum sanctum) dan Mat Serbuk Daun Pandan Wangi (Pandanus amaryllifolius) sebagai Repellent terhadap Nyamuk Aedes sp". Hasil penelitian menunjukkan Mat elektrik yang paling disukai yaitu mat elektrik dari serbuk daun pandang wangi (Pandanus amaryllifolius) sebesar 76,7\% [17].

Secara deskriptif formulasi ekstrak biji ketumbar memiliki daya repellent yang berbeda-beda, berdasarkan tabel kelima, maka rata-rata jumlah Aedes sp. setelah pengamatan 10 menit pertama setiap jam dari pengulangan pertama sampai pengulangan keenam pada kelompok kontrol dan eksperimen dengan penambahan ekstrak biji ketumbar mengenai jumlah dan rata-rata dalam kemampuan menolak Aedes sp., jumlah nyamuk yang menghindar terbanyak pada formulasi C yaitu 94 ekor dengan rata-rata 15,7 ekor setiap jamnya dan jumlah nyamuk yang menghindar paling sedikit pada kelompok kontrol sebanyak 23 ekor dengan rata-rata 3,8 ekor setiap jamnya.

Berdasarkan analisis statistik diketahui bahwa antar formulasi A,B dan C memiliki pengaruh yang signifikan $H \alpha=0,000$, sedangkan hasil uji LSD menunjukkan bahwa formulasi A, B dan C memiliki pengaruh yang signifikan terhadap daya repellent nyamuk Aedes sp. Penelitian mengenai pengaruh formulasi ekstrak biji ketumbar (Coriandrum sativum) dalam Gel Air Freshener sebagai repellent terhadap daya tolak nyamuk Aedes sp. telah memberikan bukti bahwa ekstrak biji ketumbar (Coriandrum sativum) mempunyai 
kemampuan daya repellent terhadap Aedes sp dengan daya repellent ekstrak biji ketumbar yang diperoleh dalam peneitian ini sebesar 62,7\%, walaupun daya repellent masih dibawah Standar Nasional yang diperlakukan untuk pengujian repellent berbahan aktif kimia yaitu $90 \%$.

Pemanfaatan bahan aktif dari ekstrak biji ketumbar sebagai repellent meupakan alternatif untuk mencegah gigitan nyamuk Aedes sp. sehingga dapat menurunkan angka kejadian penyakit

\section{KESIMPULAN DAN SARAN}

Berdasarkan hasil penelitian dapat disimpulkan bahwa penggunaan Gel Air Freshener ekstrak biji ketumbar (Coriandrum sativum) dengan formulasi A, $\mathrm{B}$ dan $\mathrm{C}$ sebagai repellent bagi nyamuk Aedes sp berpengaruh secara bermakna terhadap perbedaan jumlah nyamuk yang menghindar ( $\mathrm{p}<0,005)$. Adapun Gel Air Freshener ekstrak biji ketumbar (Coriandrum sativum) yang paling efektif sebagai repellent nyamuk Aedes sp adalah formulasi $\mathrm{C}$ dengan daya repellent $62,7 \%$.

Masyarakat disarankan untuk menggunakan formulasi C sebagai repellent terhadap nyamuk Aedes sp. Bagi yang ingin melanjutkan penelitian ini disarankan untuk meneliti penggunaan $\mathrm{Gel}$ Air Freshener ekstrak biji ketumbar (Coriandrum sativum) dengan meningkatkan formulasi, memperpanjang waktu pengamatan, dan menggunakan sampel 25 ekor nyamuk disetiap pengamatan. Penelitian untuk melakukan inovasi terhadap biji ketumbar (Coriandrum sativum) menjadi anti nyamuk dalam bentuk lain juga disarankan untuk dilakaukan.

\section{KEPUSTAKAAN}

1. Soedarto. Penyakit Menular Indonesia. Jakarta: CV Sagung Seto; 2009.

2. Permenkes RI No 374. 2010;(Pengendalian Vektor).

3. Sucipto CD. Vektor Penyakit Tropis (pertama). Yogyakarta: Gosyen Publishing; 2011.

4. DInkes Kabupaten Sleman. Profil
Deman Berdarah Dengue (DBD), namun penelitian vektor/ binatang pengganggu tidak cukup dengan sau cara, tetapi dengan pengendalian beberapa usaha terpadu seperti pengendalian secara fisik, biologi, kimia dan modifikasi lingkungan. Pengendalian secara terpadu dan terus berkesinambungan diharapkan dapat menjadi solusi terbaik untuk tercapainya pengendalian berbagai macam vektor dari penyakit yang aman, mudah dan ekonomis serta dapat menurunkan angka kejadian penyakit terutama DBD.

Kesehatan Sleman 2013. 2013;

5. Depkes RI. Rencana Strategi Departemen Kesehatan. Jakarta: Depkes RI; 2005.

6. Hatuti O. Demam Berdarah Dengue. Yogyakarta: Kanisius; 2008.

7. Anonim. Bahaya DEET Pada InsectReppelent. 2011;

8. Rusli M. S. Sukses Memproduksi Minyak Atsiri (pertama). Jakarta: PT. Agro Media Pustaka; 2010.

9. Agusta A. Minyak Atsiri Tumbuhan Tropika Indonesia. Bandung: ITB Bandung; 2000.

10. Astawan M. Ketumbar. 2009;

11. Dinata. Mengenal Hama Pemakan Daun Kedelai: Ulat Grayak (Spodoptera litura). 2011;

12. Robinson $\mathrm{T}$. Kandungan Organik Tumbuhan Tinggi. Bandung: ITB Bandung; 1995.

13. Sudarmo S. Pestisida Untuk Tanaman. Yogyakarta: Kanisius; 1992.

14. Kardinan A. Potensi Selasih Sebagai Repellent Terhadap Nyamuk Aedes aegypti. Litri Bogor 2007;

15. Kriswandari N. Pengaruh Variasi Konsentrasi Ekstrak Bunga Kamboja (Plumeria Alba) Dalam Lotion Sebagai Repellent Terhadap Daya Tolak Nyamuk Aedes Sp. 2015;

16. Ikhsanudin A. Formulasi Vanishing Cream Minyak Atsiri Rimpang Jahe (Zingiber Officinale Roxb) Dan Uji Aktivitas Repelan Terhadap Nyamuk Aedes Aegypti Betina. 2012; 